\title{
(H)IF applicable: promotion of neurogenesis by induced HIF-2 signalling after ischaemia
}

\author{
Tristan Leu $^{1} \cdot$ Joachim Fandrey ${ }^{1}$ (i) $\cdot$ Timm Schreiber $^{1,2}$
}

Received: 8 March 2021 / Revised: 16 June 2021 / Accepted: 23 June 2021 / Published online: 12 July 2021

(c) The Author(s) 2021

\begin{abstract}
HIF-2 represents a tissue-specific isoform of the hypoxia-inducible factors (HIFs) which regulate oxygen homeostasis in the cell. In acute oxygen deficiency, HIF transcription factors ensure the timely restoration of adequate oxygen supply. Particularly in medical conditions such as stroke, which have a high mortality risk due to ischaemic brain damage, rapid recovery of oxygen supply is of extraordinary importance. Nevertheless, the endogenous mechanisms are often not sufficient to respond to severe hypoxic stress with restoring oxygenation and fail to protect the tissue. Herein, we analysed murine neurospheres without functioning HIF- $2 \alpha$ and found that special importance in the differentiation of neurons can be attributed to HIF-2 in the brain. Other processes, such as cell migration and signal transduction of different signalling pathways, appear to be mediated to some extent via HIF-2 and illustrate the function of HIF-2 in brain remodelling. Without hypoxic stress, HIF-2 in the brain presumably focuses on the fine-tuning of the neural network. However, a therapeutically increase of HIF-2 has the potential to regenerate or replace destroyed brain tissue and help minimize the consequences of an ischaemic stroke.
\end{abstract}

Keywords HIF- $2 \cdot$ Ischaemia $\cdot$ Brain $\cdot$ Neurogenesis $\cdot$ Regeneration

\section{Introduction}

Neurological diseases, especially ischaemic stroke, are often associated with the loss of neurons. However, neurogenesis is limited to few areas in the brain, such as the subventricular zone (SVZ), and stem cells need to migrate to the damaged area to replace lost cells. Moreover, only a small proportion of the newly generated neurons seem to survive permanently, which is probably due to unfavourable environmental factors, insufficient connections to supporting cells and excessive confrontation with harmful processes emanating from the damaged tissue [2]. Thus, although certain regeneration mechanisms exist in our brain and the proliferation, neurogenesis and migration of neural precursor cells in certain neurogenic regions increase after damage [31], a longer survival time and integration into the existing system of

Joachim Fandrey

joachim.fandrey@uni-due.de

1 Institute of Physiology, University Duisburg-Essen, 45147 Essen, Germany

2 Institute of Physiology, Pathophysiology and Toxicology and Center for Biomedical Education and Research (ZBAF), University of Witten/Herdecke, 58453 Witten, Germany the damaged region are needed. Interestingly, many of the endogenous processes that influence the repair of cerebral damage are related to the hypoxia-inducible factor (HIF) $[6,8,14]$.

HIF is a heterodimer, whose complexity comprises a constitutively expressed HIF- $\beta$ subunit and an $\mathrm{O}_{2}$-regulated HIF- $\alpha$ subunit [42]. So far, three different $\alpha$ subunits were identified. These include HIF- $1 \alpha$, HIF- $2 \alpha$ and HIF- $3 \alpha$, whereby just for HIF- $1 \alpha$ and HIF- $2 \alpha$, it is known that they act as transcription factors by dimerizing with HIF- $\beta$ [5]. In the presence of $\mathrm{O}_{2}$ in well-oxygenated tissue continuously synthesized HIF- $\alpha$ s are hydroxylated by prolyl-4-hydroxylase domain proteins (PHDs) [12] and ultimately degraded by the proteasome. Since PHDs require oxygen for their activity, hypoxia reduces hydroxylation of HIF- $\alpha$ s and allows hypoxic accumulation to form more HIF complexes with the constitutive HIF-ß.

The activation of the HIF pathway under physiological and hypoxic conditions plays an essential role in the development of the central nervous system. With regard to neural cell development in zebrafish, HIF-2 has a protective effect on neuronal stem cells while also promoting neurogenesis [21]. HIF-2 also influences the production of apoptosis inhibitors and controls angiogenesis throughout 
the brain. This mainly affects the physiological formation of new nerve cells which is a relevant factor in recovering from pathologies such as an ischaemic stroke [28].

Therefore, HIF is particularly relevant in neurodegenerative brain diseases. In a mouse model of ischaemic stroke, a combined neuronal knockout of HIF- $1 \alpha$ and HIF- $2 \alpha$ resulted in reduced infarct size in the early acute phase during the first $24 \mathrm{~h}$ of reperfusion; this effect was lost after $72 \mathrm{~h}$ of reperfusion when no differences in infarct size were seen [22]. A reduced expression of anti-survival genes by HIF in the early acute phase might have led to increased apoptotic cell death and reduced angiogenesis. Interestingly, the enhanced accumulation of HIF by a knockout of PHD2 in neurons reduced the infarct size in a mouse stroke model by more than 50\% [22]. This implies that special emphasis should be placed on the timing and cell type-specific activation or inhibition of HIF-regulated cytoprotective factors to consider HIF-controlled treatment options in stroke therapy.

Due to the neuroprotective effects of HIF-2 described above, we focused on the specific role of HIF-2 during the regeneration from ischaemic brain damage to reveal its role in responding to local or systemic oxygen deficiency in the brain.

\section{Experimental procedures}

\section{Animals}

All experiments were performed with male and female C57BL/6 J mice. To obtain mice with a neuronal-specific Hif- $2 \alpha$, knockout mice homozygous for loxP sites covering exon 2 of the Hif- $2 \alpha$ gene which encodes for the DNA binding domain of the transcription factor $\left(\right.$ Hif- $2 \alpha^{+f /+f l}$, purchased from the Jackson Laboratory, Bar Harbor, ME, USA) were crossed with mice heterozygously expressing Cre recombinase under the control of the nestin promoter (B6. $\mathrm{Cg}-\mathrm{Tg}$ (Nes-cre) $1 \mathrm{~K} \ln / \mathrm{J}$, purchased from the Jackson Laboratory, Bar Harbor, ME, USA). Nestin is already expressed in neuroepithelial cells that form the neural plate and then the neural tube [16]. As a result, all cell types in the brain carry the knockout, since all cell types descend from these cells. Littermates negative for CRE recombinase but $H i f-2 \alpha^{+f l /+f l}$ served as control animals. All animals showed a physiological habitus and normal breeding behaviour. Complete pelleted feed and drinking water were administered ad libitum. The keeping and breeding of the animals took place in compliance with the German law for animal welfare and was approved by the State Agency for Nature, Environment and Consumer Protection North Rhine-Westphalia (file reference, 84-02. 04. 2016. A173).

\section{Cell culture}

To obtain neural stem and progenitor cells, mice aged p1-p3 were killed by decapitation, and the head was transferred to sterile PBS. Further preparations were carried out in minimal essential medium (MEM; Thermo Fisher, Waltham, MA, USA). Cranial skin, the skullcap and the meninges were carefully removed, and the cerebral cortices were isolated. Both hemispheres were enzymatically digested with $30 \mathrm{U} /$ $\mathrm{mL}$ papain (Worthington, Freehold, NJ, USA) for $20 \mathrm{~min}$ at $37^{\circ} \mathrm{C}$ to obtain single-cell suspensions. Subsequently, $1 \mathrm{ml}$ of the supernatant was discarded, and digestion was terminated by adding $1 \mathrm{ml}$ of ovomucoid $(1 \mathrm{mg} / \mathrm{ml}$ trypsin inhibitor (Merck KGaA, Darmstadt, Germany), $50 \mu \mathrm{g} / \mathrm{ml}$ BSA and $40 \mu \mathrm{g} / \mathrm{ml}$ DNaseI (Worthington, Freehold, NJ, USA) in MEM). Cells were centrifuged for $5 \mathrm{~min}$ at $300 \mathrm{~g}$, the supernatant was completely discarded, and the resulting cell pellet dissolved in $1 \mathrm{ml}$ neurosphere medium (DMEM/F-12 (1:1, Thermo Fisher, Waltham, MA, USA) containing $0.2 \mathrm{mg} / \mathrm{ml}$ L-glutamine (Merck KGaA, Darmstadt, Germany), 2\% v/v B27 supplement (Thermo Fisher, Waltham, MA, USA), 100 $\mathrm{U} / \mathrm{ml}$ penicillin and $100 \mu \mathrm{g} / \mathrm{ml}$ streptomycin (both Merck KGaA, Darmstadt, Germany)). Cells were cultivated as free-floating neurospheres in T25 flasks (bulk culture) at a density of $10^{5}$ cells $/ \mathrm{ml}$ in neurosphere medium in the presence of $20 \mathrm{ng} / \mathrm{mL}$ epidermal growth factor (EGF) and basic fibroblast growth factor (bFGF, PreproTech $\mathrm{GmbH}$, Hamburg, Germany) at $37^{\circ} \mathrm{C}$ in $20.9 \% \mathrm{O}_{2} / 5 \% \mathrm{CO}_{2}$. The neurospheres were cultivated for 12-16 days, changing half of the medium every 3-4 days supplemented with $20 \mathrm{ng} / \mathrm{mL}$ EGF and bFGF.

\section{Oxygen-glucose deprivation}

To simulate an ischaemic stroke, neurospheres were placed in glucose-free DMEM-F12 medium for 1 to $4 \mathrm{~h}$ at $0.2 \%$ $\mathrm{O}_{2}$ in the hypoxia chamber resulting in oxygen-glucose deprivation (OGD). Neurospheres were lysed for RNA and protein extraction after $60 \mathrm{~min}$ each in the corresponding buffer (treatment \# 1). For the additional reperfusion, the neurospheres were transferred in neurosphere medium and incubated for $1 \mathrm{~h}$ at $20.9 \% \mathrm{O}_{2}$ (treatment \# 2). The migration of the neurospheres was studied with special differentiation medium for $24 \mathrm{~h}$ (neurosphere medium containing $1 \% \mathrm{v} / \mathrm{v}$ FCS (Merck KGaA, Darmstadt, Germany); treatment \# 3).

\section{Migration assay}

For measurement of the cellular migration properties before and after OGD, the migration and differentiation were initiated in a four-part cell culture dish (Greiner Bio One, 
Kremsmuenster, Austria) coated with $10 \mu \mathrm{g} / \mathrm{ml}$ poly-ornithine and $10 \mu \mathrm{g} / \mathrm{ml} 445$ laminin-1 (Merck KGaA, Darmstadt, Germany) in neurosphere medium containing 1\% v/v FCS (Merck KGaA, Darmstadt, Germany). Migration distance was measured from the edge of the sphere to the farthest migrated cells at four defined positions per sphere after 24, 48 and $72 \mathrm{~h}$. The initial size of the neurospheres was not included in the migration distance, since the migration speed is independent of the size of the sphere [26].

\section{Polymerase chain reaction}

Total RNA was isolated from neurospheres with the NucleoSpin RNA kit (MACHEREY-NAGEL GmbH \& Co. KG, Düren, Germany). cDNA was synthesized using M-MLV reverse Transcriptase (Promega GmbH, Walldorf, Germany), and qPCR analysis was performed with Biozym Blue S'Green qPCR-Kit (Biozym Scientific GmbH, Oldendorf, Germany) on Bio-Rad's CFX96 ${ }^{\mathrm{TM}}$ real-time system (Bio-Rad Laboratories GmbH, Feldkirchen, Germany). The following primer pairs were used: Bcl2 5'-ATGCCT TTGTGGAACTATATGGC-3' forward and 5'-GGTATG CACCCAGAGTGATGC-3' reverse; Cdk5r1 5'-CTGTCC CTATCCCCCAGCTAT-3' forward and 5'-GGCAGCACC GAGATGATGG-3' reverse; Cdknla 5'-CGAGAACGG TGGAACTTTGAC-3' forward and 5'-CCAGGGCTC AGGTAGACCTT-3' reverse; Cited2 5'-CGCCAGGTT TAACAACTCCCA-3' forward and 5'-TGCTGGTTTGTC CCGTTCAT-3' reverse; Cxcll 5'-CTGGGATTCACCTCA AGAACATC-3' forward and 5'-CAGGGTCAAGGCAAG CCTC-3' reverse; Epo 5'-ACTCTCCTTGCTACTGAT TCCT- 3 ' forward and 5'-ATCGTGACATTTTCTGCC

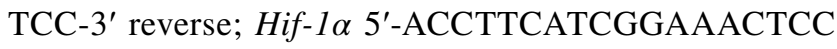
AAAG-3' forward and 5'-CTGTTAGGCTGGGAAAAG TTAGG-3' reverse; Hif-2 $\alpha$ exon 2 5'-AGGAGACGGAGG TCTTCTATGA- $3^{\prime}$ forward and $5^{\prime}$-ACAGGAGCTTAT GTGTCCGA-3' reverse; Ldha 5'-TGTCTCCAGCAAAGA CTACTGT-3' forward and 5'-GACTGTACTTGACAA TGTTGGGA-3' reverse; NeuroD1 5'-ATGACCAAATCA TACAGCGAGAG-3' forward and 5'-TCTGCCTCGTGT TCCTCGT-3' reverse; $N g f$ 5'-CCAGTGAAATTAGGC TCCCTG-3' forward and 5'-CCTTGGCAAAACCTTTAT TGGG-3' reverse; Notchl 5'-GATGGCCTCAATGGGTAC AAG-3' forward and 5'-TCGTTGTTGTTGATGTCACAGT3' reverse; $\mathrm{Nrg} 1$ 5'-ATGGAGATTTATCCCCCAGACA-3' forward and 5'-GTTGAGGCACCCTCTGAGAC-3' reverse; Olig2 5'-TCCCCAGAACCCGATGATCTT-3' forward and 5'-CGTGGACGAGGACACAGTC-3' reverse; Phd2 5'-TTG TTACCCAGGCAACGGAAC-3' forward and 5'-CCTTGG CGTCCCAGTCTTT-3' reverse; Phd3 5'-AGGCAATGG TGGCTTGCTATC-3' forward and 5'-GCGTCCCAATTC TTATTCAGGT-3' reverse; Rpll3a 5'-CTGTGAAGGCAT CAACATTTCTG-3' forward and 5'-GACCACCATCCG
CTTTTTCTT-3' reverse; and Vegfa 5'-ACTGGACCCTGG CTTTACTG-3' forward and 5'-ACTTGATCACTTCAT GGGACTTCT-3' reverse. Genes of interest were normalized to 60S ribosomal protein L13a (Rpl13a) as indicated. Expression was calculated with the $2^{-\Delta \mathrm{CT}}$ method.

\section{Immunofluorescence analysis}

For immunofluorescence staining, cells were fixed with $4 \%$ PFA. Cells were permeabilized for $10 \mathrm{~min}$ in $0.3 \%$ PBS-T, non-specific binding sites blocked with $10 \%$ goat serum/ PBS-T within $60 \mathrm{~min}$, and antibodies were diluted in $0.1 \%$ PBS-T. The following antibodies were used: 1:200 anti- $\beta$ Tubulin-III IgG (Sigma-Aldrich, Inc., \#T2200) and 1:200 Alexa Fluor® 488 goat anti-rabbit IgG (Life Technologies, \# A32731) for visualization of neurons; 1:200 anti-glial fibrillary acidic protein (GFAP) (Merck Millipore, \#MAB360) and Alexa Fluor ${ }^{\circledR} 568$ goat anti-mouse IgG (Invitrogen AG, \#A11004) for visualization of astrocytes; anti-Marker O4 IgM (R\&D Systems, \#MAB1326) and Alexa Fluor® 488 goat anti-mouse IgG (Life Technologies, \#A11001) for visualization of oligodendrocytes. For additional visualization of the nuclei, cells were covered with DAPI-added Mowiol.

\section{Western blot}

Western blot analysis was performed as previously described [45] with $20 \mu \mathrm{g}$ protein lysate per line. The following antibodies were used: 1:500 anti-HIF-1 $\alpha$ (Cayman Chemical, $\# 10,006,421)$ and 1:1000 anti- $\alpha$-Tubulin (Santa Cruz Biotechnology, \#sc-8035).

\section{Statistics}

The software GraphPad Prism ${ }^{\circledR}$ version 8.0.2 from GraphPad Software, Inc. was used to evaluate the results. Statistical significance was determined using unpaired, two-tailed Student's t-test. For all quantified data, mean \pm SEM values are presented. A p-value $\leq 0.05$ was considered as statistically significant $(\mathrm{p} \leq 0.05=*)$. Significances in relation to the corresponding control group were marked with a \# $(\mathrm{p} \leq 0.05=\#)$.

\section{Results}

To determine the role of HIF- $2 \alpha$ in stroke, we used an in vitro neurosphere assay. Neural stem cells (NSCs) were isolated from wild-type mouse pups ( $H$ if $\left.-2 \alpha^{+f / / f f}\right)$ and littermates without active HIF-2 $\alpha$ protein $\left(\mathrm{Hif}-2 \alpha^{-/-}\right)$and grown as neurospheres. Subsequently, spheres were treated with oxygen-glucose deprivation (OGD), as depicted in Fig. 1a, to simulate cerebral ischemia in vitro. OGD time points 


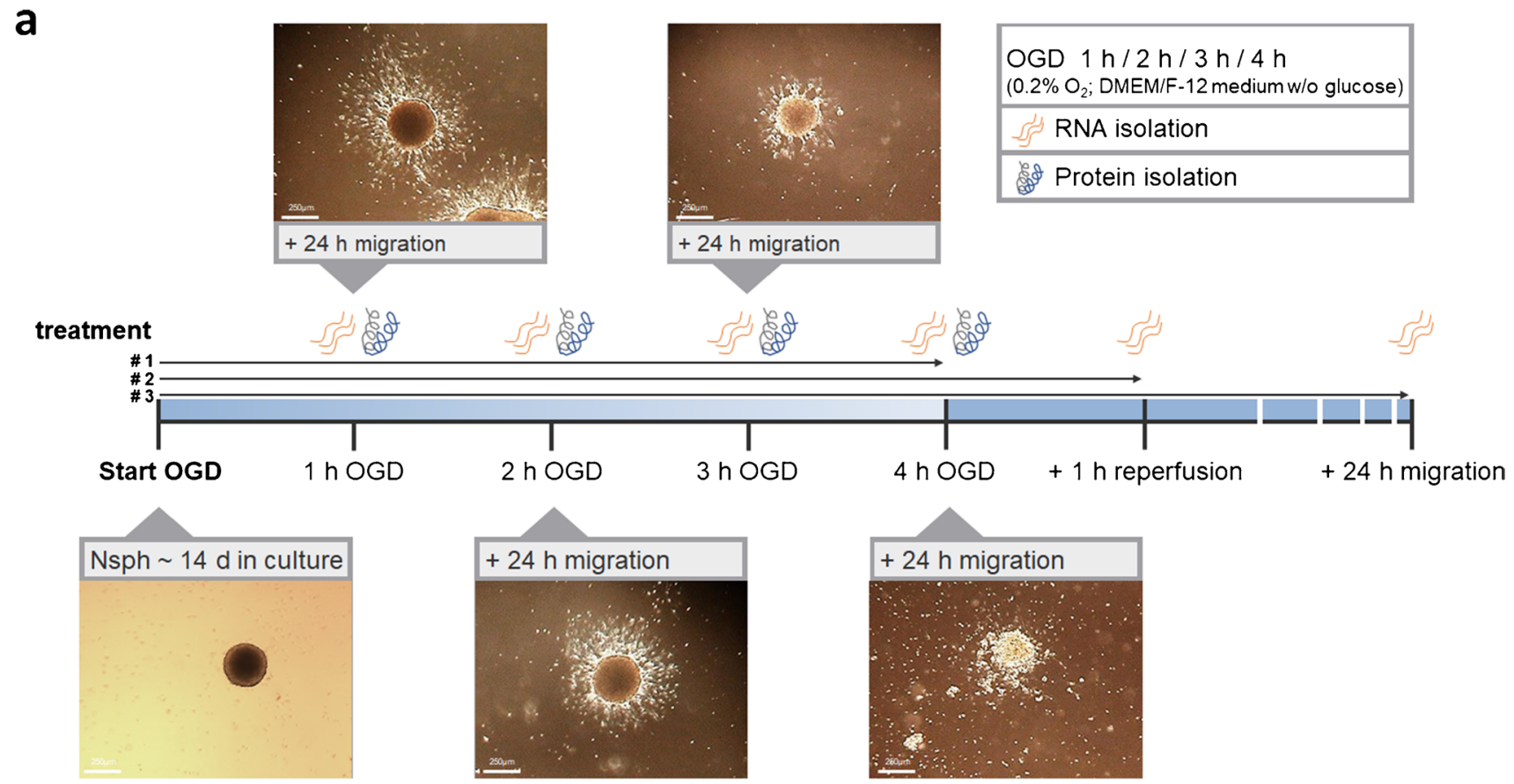

\section{b}

Migration after OGD

Migration

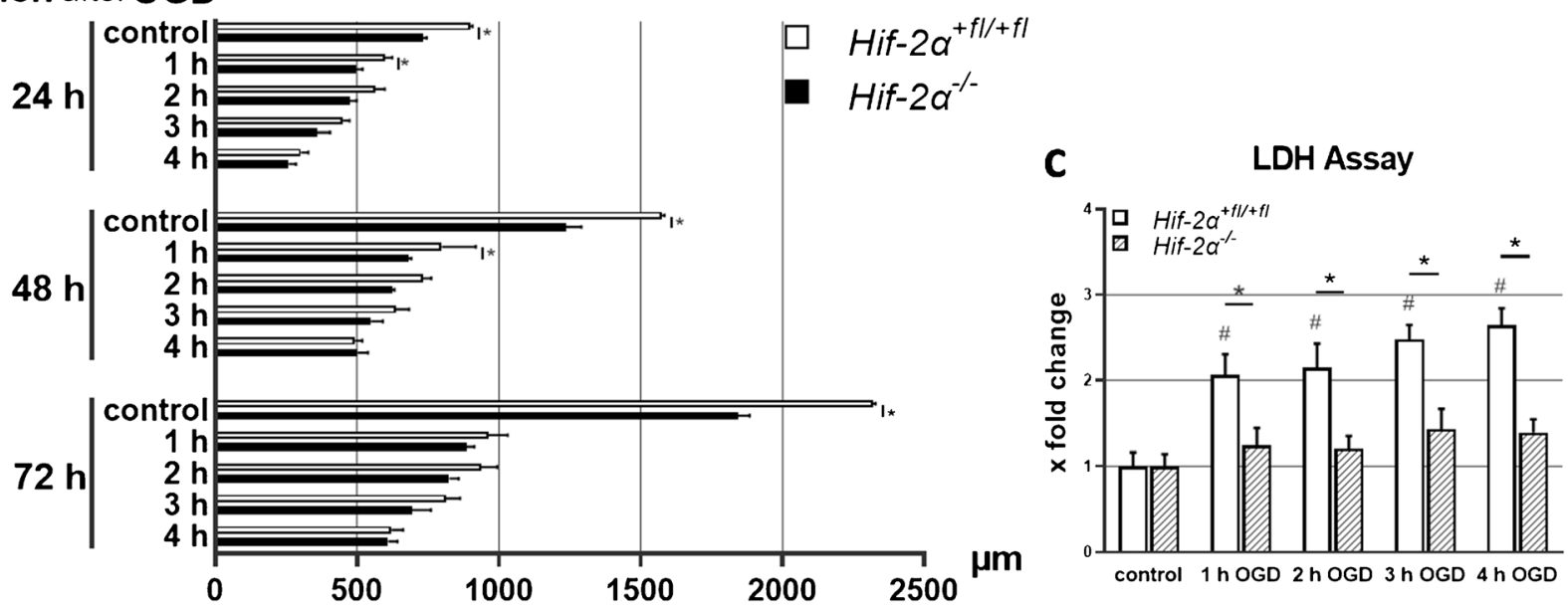

Fig. 1 OGD treatment reduces migration and enhances mortality of neural cells. a Schematic of OGD treatment simulating an ischemic stroke in vitro with neurospheres. b Measurement of migration distances after OGD and 24, 48 and $72 \mathrm{~h}$ of migration $(\mathrm{n}=3)$. c Meas-

longer than $4 \mathrm{~h}$ were not possible due to complete cell decay under the OGD conditions. To investigate the influence of HIF-2 $\alpha$ during reperfusion and regeneration, we reperfused the spheres with normoxia and glucose-containing medium for $1 \mathrm{~h}$, and let the spheres differentiate for up to $72 \mathrm{~h}$.

First, to analyse basic cell properties and to test the function of the cells, we measured the distance that wild-type and Hif- $2 \alpha$ knockout cells migrated from the spheres after OGD treatment (Fig. 1b). These measurements showed that the cells migrated radially away from the spheres urement of lactate dehydrogenase in the culture medium during OGD for determining mortality rate $(n=5)$. Data are presented as mean \pm SEM; *p $<0.05$

with increasing differentiation time, whereby migration was impaired in Hif- $2 \alpha^{-/-}$cells. OGD treatment robustly decreased the migration distance up to $75 \%$ in wild-type as well as in knockout cells. Interestingly, wild-type cells were more strongly affected than knockout cells, and their advantage in migration steadily disappeared with increasing OGD duration.

Cells are enormously stressed during ischaemia. Therefore, we tested cell viability with an LDH assay after OGD. LDH release in $H i f-2 \alpha^{+f /+f l}$ cultures increased moderately 
but significantly with ongoing OGD duration (Fig. 1c). Interestingly, the viability of $\mathrm{Hif-} 2 \alpha^{-/-}$spheres appeared to be unaffected by OGD.

Various studies have shown that HIF isoforms potentially compensate for each other [36]. Therefore, we analysed HIF-1 $\alpha$ protein stabilization after OGD. As expected, HIF- $1 \alpha$ was increasingly stabilized during increasing OGD duration. We also found that after $4 \mathrm{~h}$ of OGD, the amount of HIF- $1 \alpha$ accumulated significantly more in the Hif- $2 \alpha^{-/-}$cells compared to Hif- $2 \alpha^{+f l+f l}$ cells (Fig. 2 a). Hif- $1 \alpha$ mRNA expression did not show any differences, neither between Hif- $2 \alpha^{+f l / f l}$ and $H i f-2 \alpha^{-/-}$nor during OGD.

To verify increased transcriptional activity by HIF- $1 \alpha$ accumulation after loss of HIF-2 $\alpha$, we looked for the expression of the known HIF target genes Vegf and Epo. Here, Vegf expression increased steadily during OGD in the wild-type spheres but was unaffected in the knockout cells (Fig. 2b). Epo expression rose with ongoing OGD in both genotypes, with stronger increase in the wild-type. HIF- $1 \alpha$ seems to compensate for the loss of HIF- $2 \alpha$ in the case of ischaemia to some extent, although the known HIF target genes Epo and Vegf seem to be regulated by HIF- $2 \alpha$ not HIF- $1 \alpha$ in NSCs. Collectively, the loss of HIF- $2 \alpha$ seems to be beneficial for NSCs in the event of ischaemia, presumably due to increased HIF-1 $\alpha$ stabilization.

As loss of HIF- $2 \alpha$ changes migration capabilities and OGD susceptibility, we wanted to clarify which cell types are among the migrating cells and how they are affected by OGD. Therefore, we performed immunofluorescence staining after 1 -h reperfusion and $72 \mathrm{~h}$ of differentiation. The quantification of immunoreactive cells for $\beta($ III) tubulin showed that the number of neurons in the migration area decreased in Hif- $2 \alpha^{+f /+f l}$ and Hif- $2 \alpha^{-/-}$spheres with ongoing OGD duration (Fig. 3). After $4 \mathrm{~h}$ of OGD, the number of neurons decreased by roughly $50 \%$ in wild-type and $75 \%$ in KO spheres. Oligodendrocytes were even more susceptible than neurons; their number decreased by more than $80 \%$ in both genotypes after $4 \mathrm{~h}$ of OGD, without any difference between KO and WT. The cell count of astrocytes fluctuated around control values until an increase in the Hif- $2 \alpha^{-/-}$spheres after $4 \mathrm{~h}$ of OGD. At this time point, migration behaviour of astrocytes appeared somewhat more disordered, but this was not constantly observed in all neurospheres. Here, we showed that OGD led to a reduced differentiation of NSCs into neurons and oligodendrocytes. The functional loss of HIF- $2 \alpha$ caused an even greater reduction of neurons, but to an increased number of astrocytes.

Since a modified Hif- $1 \alpha$ gene expression was excluded as an explanation for the altered HIF- $1 \alpha$ accumulation, the next step was to examine HIF-regulating enzymes, namely, PHD2, PHD3 and FIH1. The constantly expressed $P h d l$ was excluded in this study. Expression of $P h d 2$ and $P h d 3$ did not differ between Hif- $2 \alpha^{+f /+f l}$ and Hif- $2 \alpha^{-/-}$and was not regulated during OGD (Fig. 2 c). However, analysis of $\mathrm{FIHI}$ expression showed a significant increase after $4 \mathrm{~h}$ of OGD in $H i f-2 \alpha^{+f l / f f}$ spheres and thus differs significantly from Hif- $2 \alpha^{-/-}$spheres.

To determine the significance of altered $F I H I$ expression, we analysed the potentially FIH-dependent HIF-2 target genes Ldha, Cited-2 and Cdknla [9]. Ldha expression did not show any changes over the entire OGD period in both genotypes (Fig. 2d). In contrast, Cited-2 showed a significant increase in Hif- $2 \alpha^{+f /+f l}$ and Hif- $2 \alpha^{-/-}$spheres already after $1 \mathrm{~h}$ of OGD, and this continued to rise during the experiment. Cdknla expression in the wild-type initially decreased after $1 \mathrm{~h}$ of OGD but increased afterwards. In the Hif- $2 \alpha^{-/-}$spheres, on the other hand, the expression did not differ throughout the entire duration of the experiment. Thus, of the three investigated genes, only Cdknla seems to be regulated by HIF-2.

As the composition of the neural cells is affected differently upon OGD in KO and wild-type neurospheres, we performed expression analyses for genes known to be associated with neuronal differentiation and survival. First, we looked for NeuroDl expression, which is essential for neuronal differentiation. NeuroDl was expressed four times higher after loss of HIF-2 $\alpha$ in the control spheres (Fig. 4a). However, OGD led only to an increase in the proficient Hif$2 \alpha^{+f l / f l}$ spheres, whereas the KO remained at control levels. Expression of $\mathrm{Nrgl}$, also important for neuronal differentiation, showed a constant increase in $H i f-2 \alpha^{+f /+f l}$ during OGD, compared to only a transient increase in $\mathrm{Hif}-2 \alpha^{-/-}$after $1 \mathrm{~h}$ of OGD. Grinl is crucial for synaptic plasticity and survival. Its expression showed a simultaneous decrease in both genotypes after $3 \mathrm{~h}$ of OGD. Interestingly, initial Grin 1 expression under normal culture conditions was significantly higher in Hif- $2 \alpha^{-/-}$compared to the wild-type.

Another candidate for maintaining neurons is $N g f$. Its expression levels increased steadily with ongoing OGD in both genotypes (Fig. 4 b). However, only Hif- $2 \alpha^{-/-}$cells showed a significant increased $N g f$ expression after 3 and $4 \mathrm{~h}$ of OGD. The role of $N g f$ in differentiation of neural stem cells does seem to be acute but represents a process of longer stimulation to have an additive effect on neural differentiation [7]. In our experimental design, we investigated the acute reaction of neural cells to the ischaemic event (up to $4 \mathrm{~h}$ OGD), which is too short a time for an effect of the NGF (nerve growth factor) protein on neuronal differentiation. However, NGF has a major influence on neuroprotection as it appears globally neuroprotective to the developing brain in a neonatal model of cerebral hypoxia-ischaemia [19]. Notchl is responsible for the differentiation of NSCs into astrocytes. During OGD, expression in Hif- $2 \alpha^{+f l /+f l}$ cells remained at control levels and showed only a mild transient increase in $\mathrm{Hif}-2 \alpha^{-/-}$spheres. Cdk5rl describes a gene whose 
a

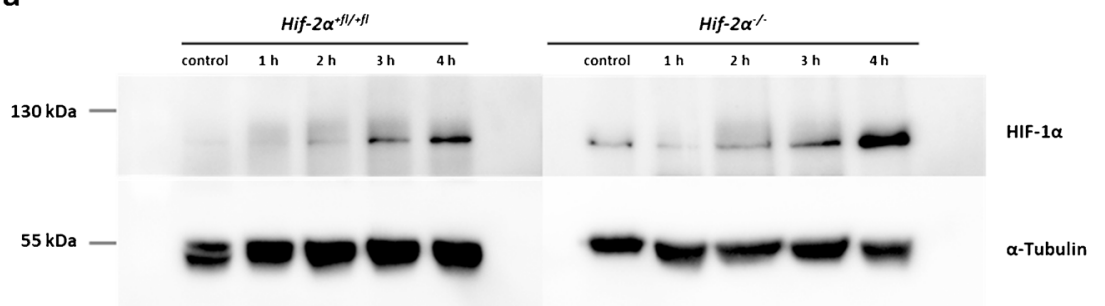

b

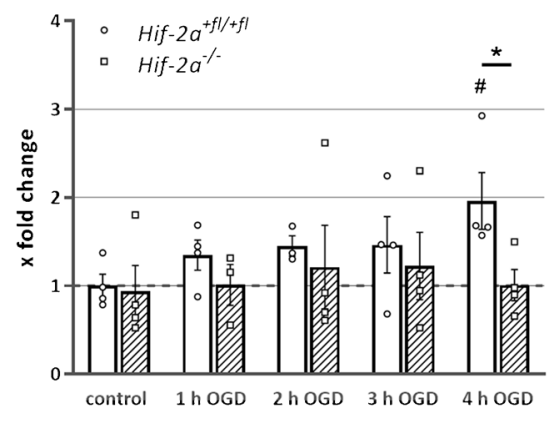

C

Phd2

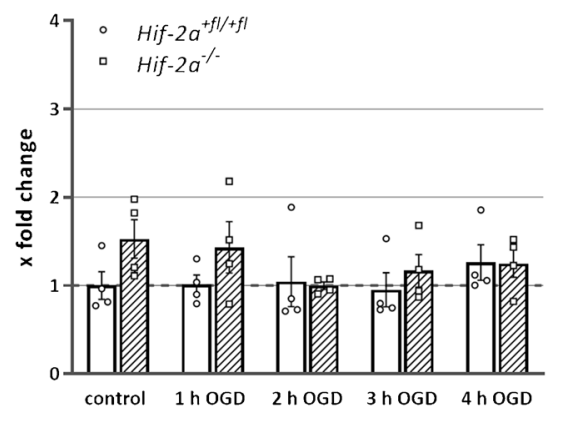

d

Ldha
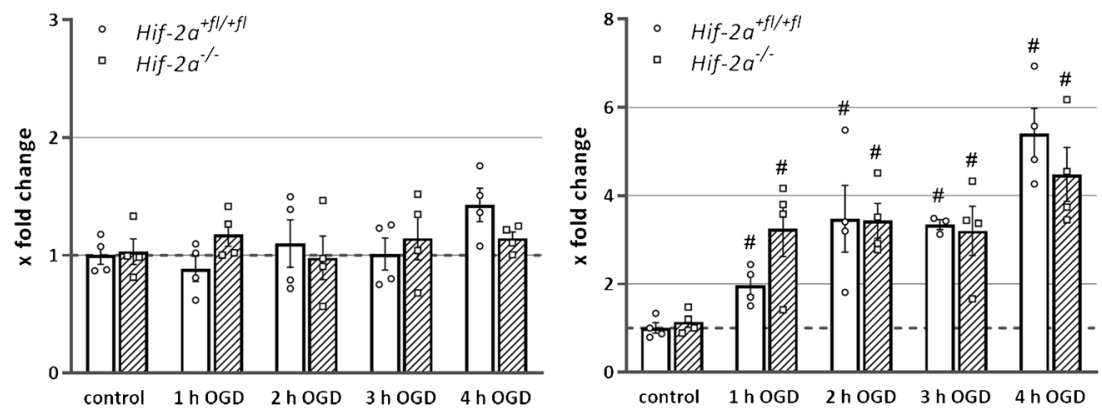

HIF-1 $\alpha$ Western Blot

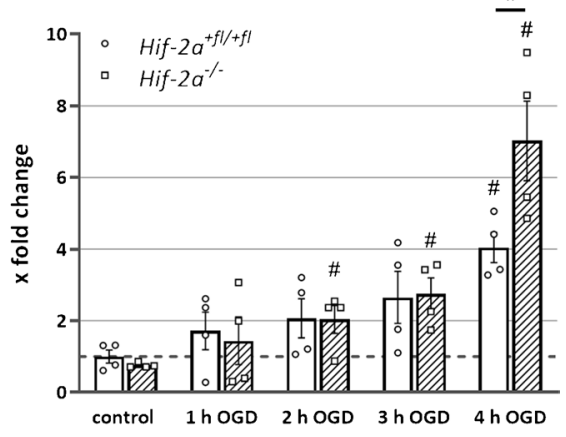

Hif1 $\alpha$

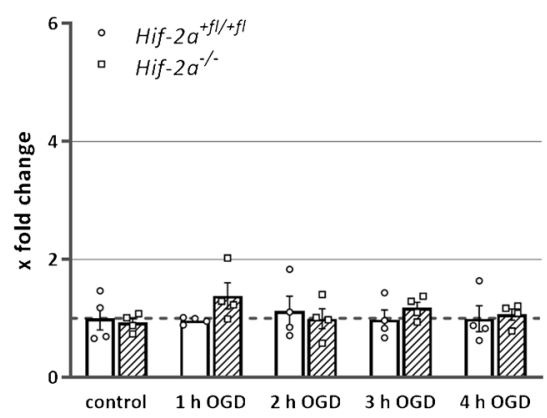

FIH1
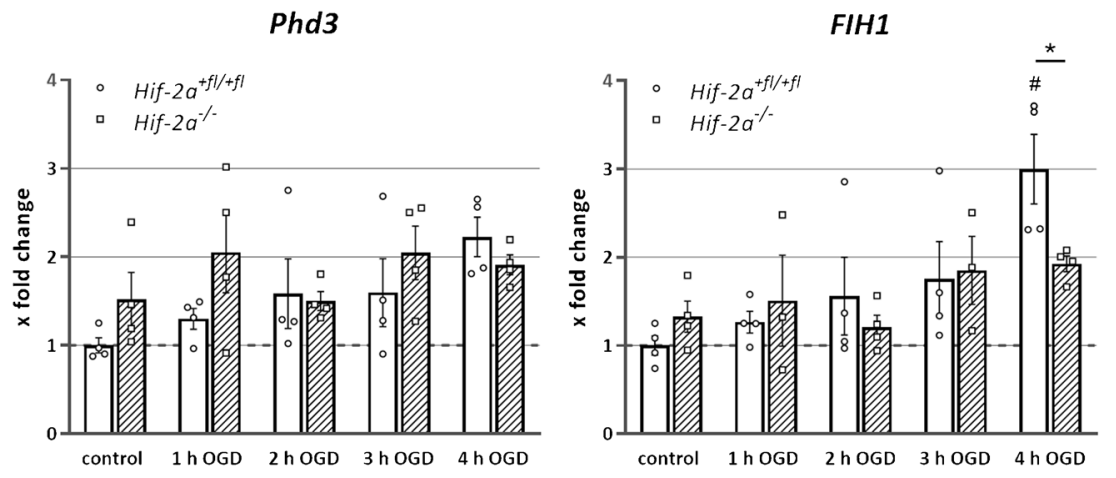

Cdkn1a

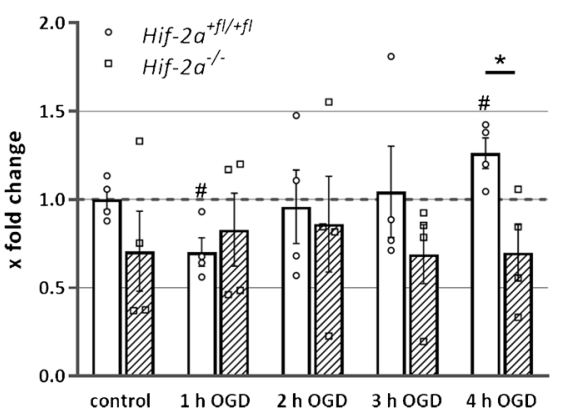

Fig. 2 HIF-2 signalling is regulated differently in neural cells. Western blot of HIF-1 and quantitative PCR analysis for specific HIF target genes or HIF signalling regulating genes. Protein and RNA from cells during different OGD time points were used. Genes were quantified and normalized for Rpl13a expression. a Western Blot analysis of HIF-1 $\alpha$ during OGD. b Known HIF target genes from tissue other than the brain. c Genes that regulate the HIF signalling pathway. d Genes potentially regulated by the FIH signalling cascade. Data are presented as mean $\pm \mathrm{SEM} ;{ }^{*} \mathrm{p}<0.05 ; \mathrm{n}=4$ with individual data points of each mouse 


\section{a \\ Hif $-2 a^{+f l /+f l}$}
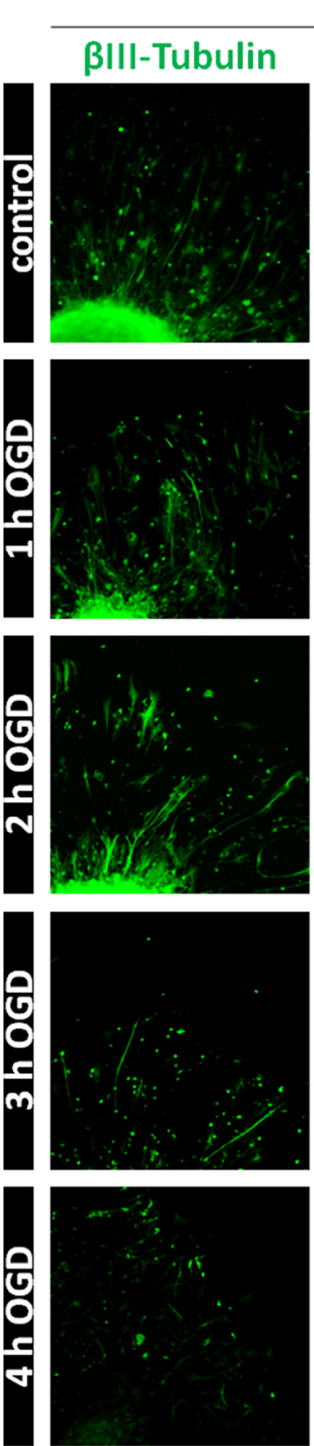

b

number of neurons

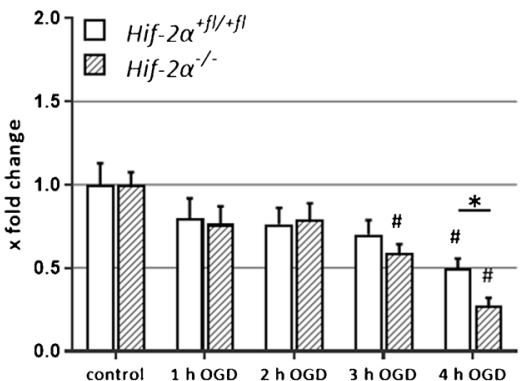

GFAP
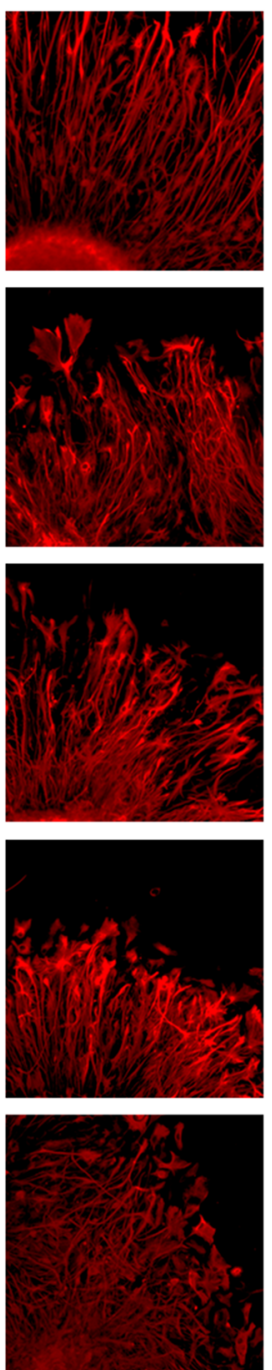

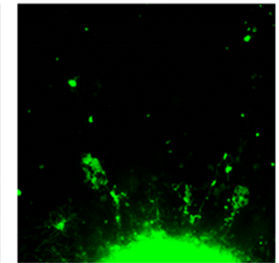

number of oligodendrocytes
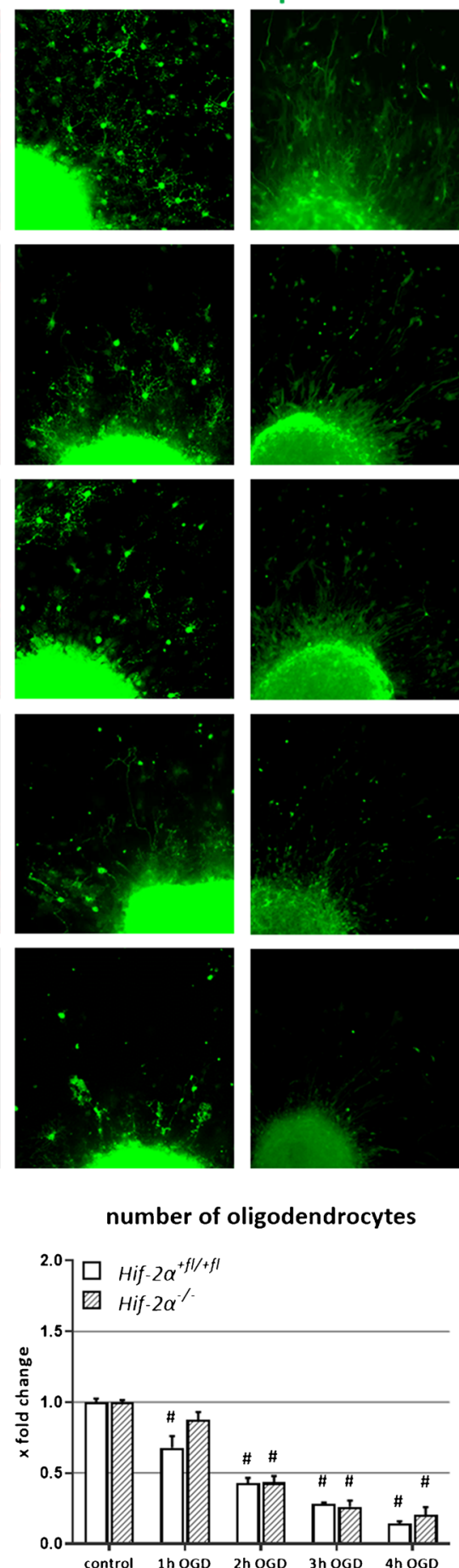

BIII-Tubulin
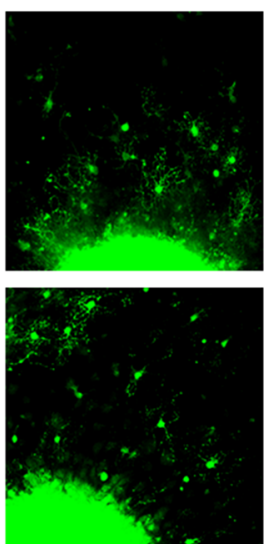

Hif-2a/-
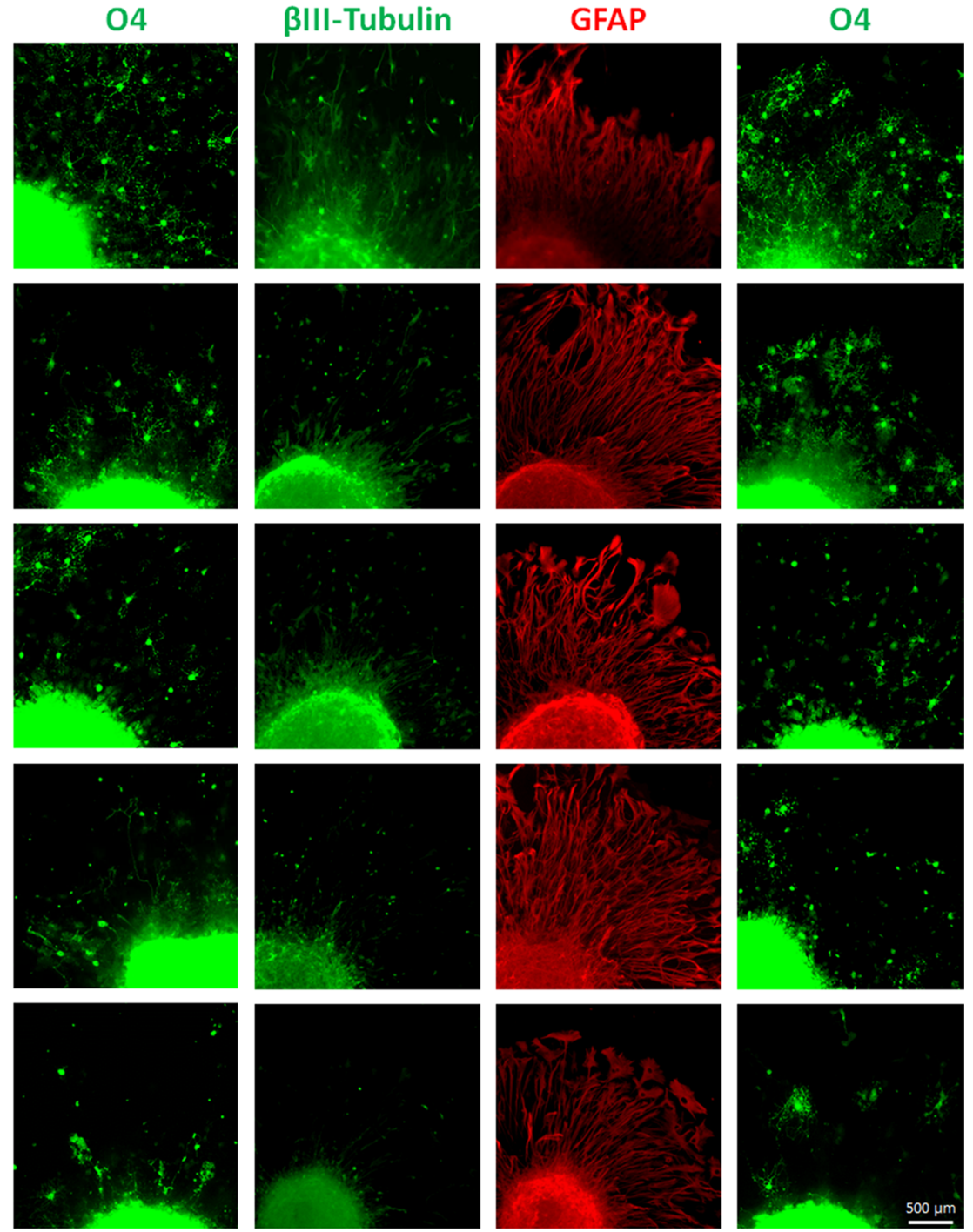

number of astrocytes

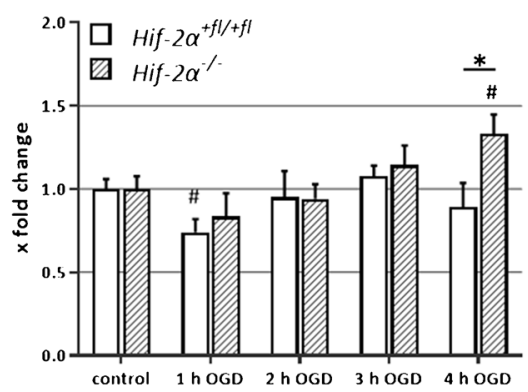

Fig. 3 Hif- $2 \alpha$ knockout in neurospheres leads to significantly less neurons after ischaemia. a Immunofluorescence staining of neurons ( $\beta$ III tubulin), astrocytes (GFAP) and oligodendrocytes (O4) migrated for $24 \mathrm{~h}$ from $\mathrm{Hif}-2 \alpha^{+f / /+f l}$ and Hif- $2 \alpha^{-/-}$neurospheres. b Relative cell number related to control. Data are presented as mean $\pm \mathrm{SEM}$; $* \mathrm{p}<0.05 ; \mathrm{n}=5$ 
a

NeuroD1

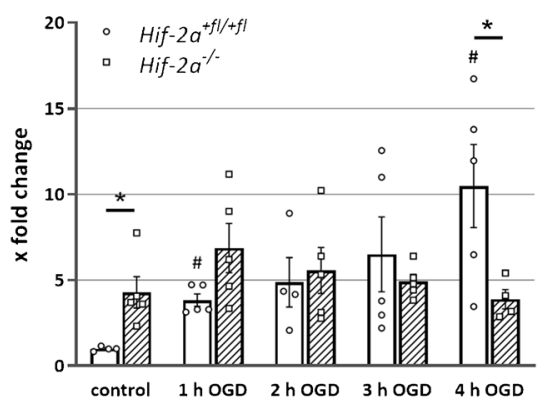

b

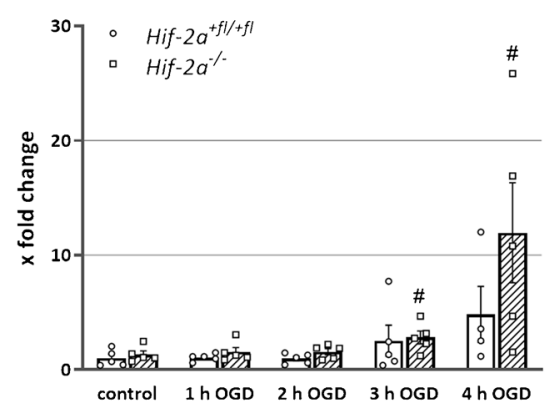

C

Olig2

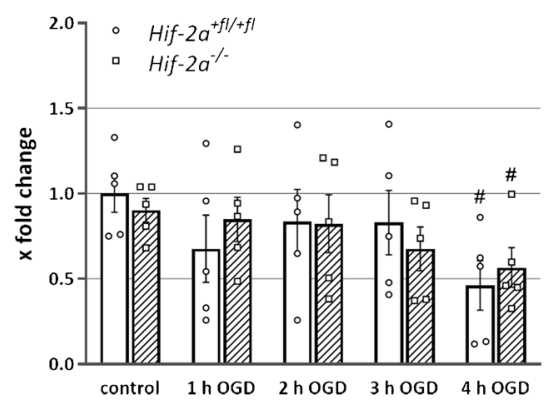

Nrg1

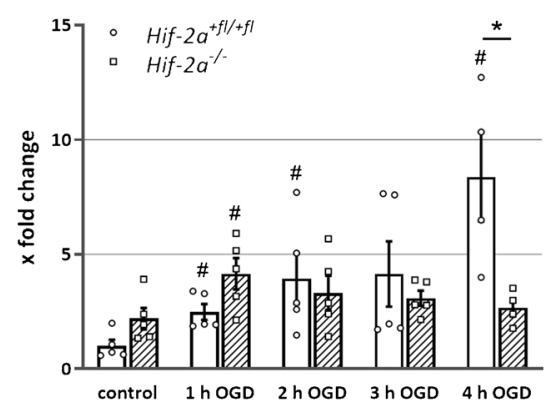

Notch1

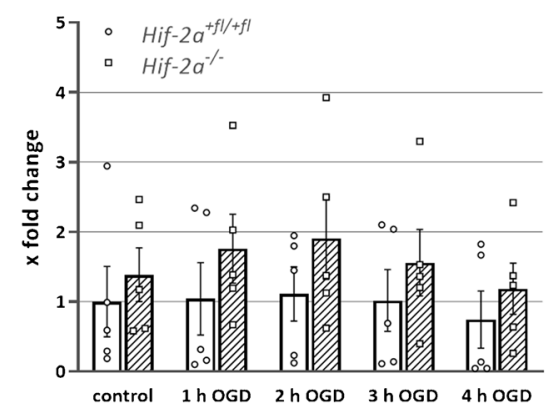

$B c / 2$

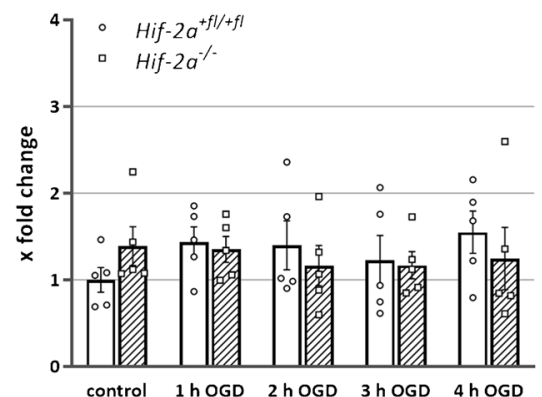

Grin1
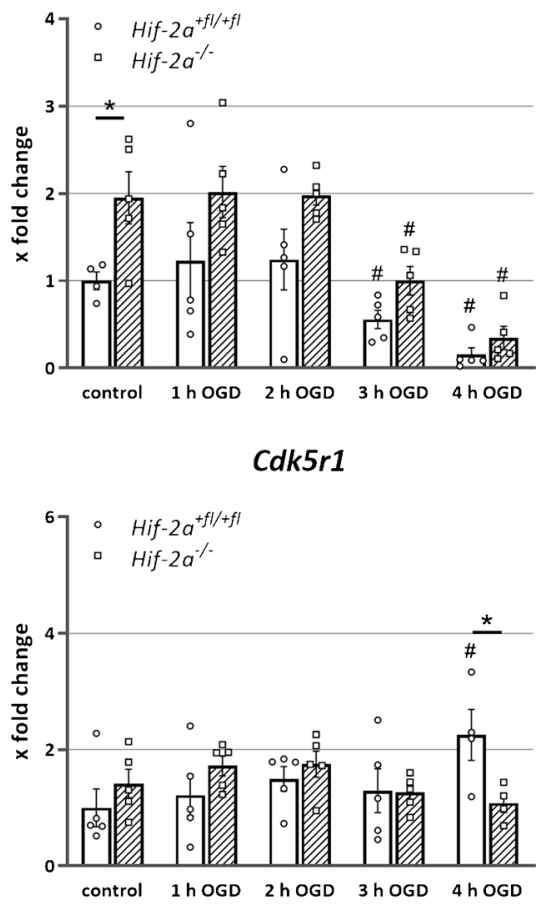

Cxcl1

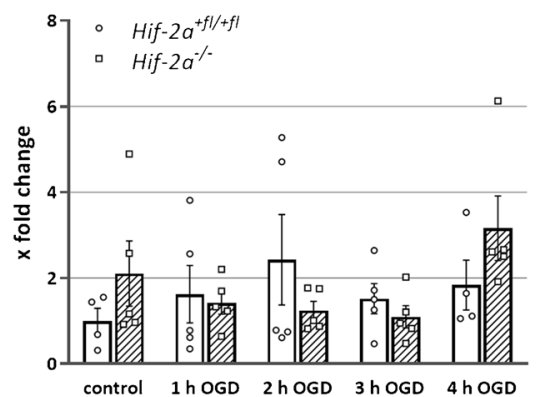

Fig. 4 HIF-2 $\alpha$ influences neuronal differentiation. Quantitative PCR analysis for genes related to cell differentiation and apoptosis. RNA from cells which migrated for $24 \mathrm{~h}$ after OGD was used. Genes were quantified and normalized for Rpl13a expression. a Neuron related genes. b Astrocyte- and apoptosis-related genes. c Oligodendrocyterelated genes. Data are presented as mean \pm SEM; $* \mathrm{p}<0.05 ; \mathrm{n}=5$ with individual data points of each mouse expression is essential for the maintenance of neuronal cells [47]. During OGD, a significant increase in $C d k 5 r 1$ expression was only seen in the wild-type spheres after $4 \mathrm{~h}$ of OGD. The expression of the Bcl2 gene, which ensures maintenance of neurons, astrocytes and oligodendrocytes, stayed at control levels in both genotypes during OGD (Fig. 4c). Cxcll, which is important for proliferation of OPCs, was unaffected during OGD. However, Olig2 decreased significantly after 4 h of OGD in both genotypes.

Thus, we showed that HIF-2 has profound effects on gene expression during ischemic events.

\section{Discussion}

Within this study, we showed that essential functions of brain regeneration are influenced by positive effects of HIF-2 on neural differentiation and that HIF-2 might be of more importance for regeneration after a stroke than HIF-1.

Here, we showed that migration under normoxic conditions without HIF-2 $\alpha$ is significantly restricted (Fig. 1) confirming previous work [20]. This suggests that HIF-2 $\alpha$ plays a crucial role in brain development to form complex 
brain structures. Across the neocortex, dozens of functionally different areas exist, like the primary visual area or the olfactory bulb. As neurogenesis is limited to a few areas in the brain, such as the SVZ, cells have to migrate from this region into these distinct areas [20]. Reduced viability causing the migration deficit after loss of HIF- $2 \alpha$ was ruled out by LDH measurement that showed increased viability without functional HIF-2. This is most likely caused by elevated HIF- $1 \alpha$ stabilization during OGD in the Hif- $2 \alpha^{-/-}$spheres. Investigation of familiar HIF target genes has shown that these are differentially regulated in the brain than in other organs. One example is VEGF, which plays an essential role in the formation of new blood vessels [13]. We found that Vegf is expressed significantly higher in Hif- $2 \alpha^{+f / / f f}$ than in $H I F-2 \alpha^{-/-}$(Fig. 2 b) indicating HIF-2 dependent expression of Vegf in the brain. However, these changes in $\operatorname{Veg} f$ expression were not found in a conditional Hif- $2 \alpha$ knockout in neurons nor in a similar Hif-1 $\alpha$ knockout [3]. Since hypoxic induction of Vegf takes place mainly in astrocytes [39], the lack of an effect of either HIF-1 or HIF-2 loss in neurons is not surprising.

HIF-2-induced Vegf expression in the brain might lead to new blood vessel formation, which would compensate for oxygen deficiency after a stroke. Since this is more of a longterm process, acute cell death can probably not be prevented in this way. One might assume that this represents more of a method to restore blood supply in regenerating tissue.

Overall, it should be mentioned that the general regulation of HIF target genes in the brain such as Ldha, Cdknla and Cited 2 shows a different pattern than in most other tissues that have been studied previously [9]. This includes different control mechanisms of HIF via FIH and PHDs as well as HIF target genes such as Epo and Vegf. All these findings describe the highly complex mechanism of HIFs and their influence on cellular response to hypoxic stress and regeneration of ischemic damaged tissue.

The relative number of neurons decreases significantly more in Hif- $2 \alpha^{-/-}$than in Hif- $2 \alpha^{+f /+f l}$ during OGD (Fig. 3b). Thus, HIF-2 may have an important function in proliferation, differentiation and/or cell survival of neurons (Fig. 5). In the case of a stroke, this would mean that HIF-2 presumably accumulates specifically in the brain in order to support differentiation of new neurons and thus promote regeneration of damaged tissue. A specific Hif- $2 \alpha$ knockout in neurons, on the other hand, did not reveal any differences in infarct size compared to control after a stroke in mice [3]. One can presume that the effects of HIF-2 in neurons are not sufficient on their own to compensate for cell loss in the damaged tissue. This fact strengthens the hypothesis that an additional induction of the astrocyte number is necessary to support migrating neurons and their integration into the infarct area. Thus, for successful regeneration of the brain, not only HIF-2 in neurons, but also in astrocytes, is necessary.

A significantly increased number of astrocytes was counted after OGD (Fig. 3b). As GFAP is also expressed in neuronal progenitors, the observed reduction in GFAP might reflect a loss in neuronal progenitors. However, the data obtained in this study are based on manual cell counts

\section{Ischemia}

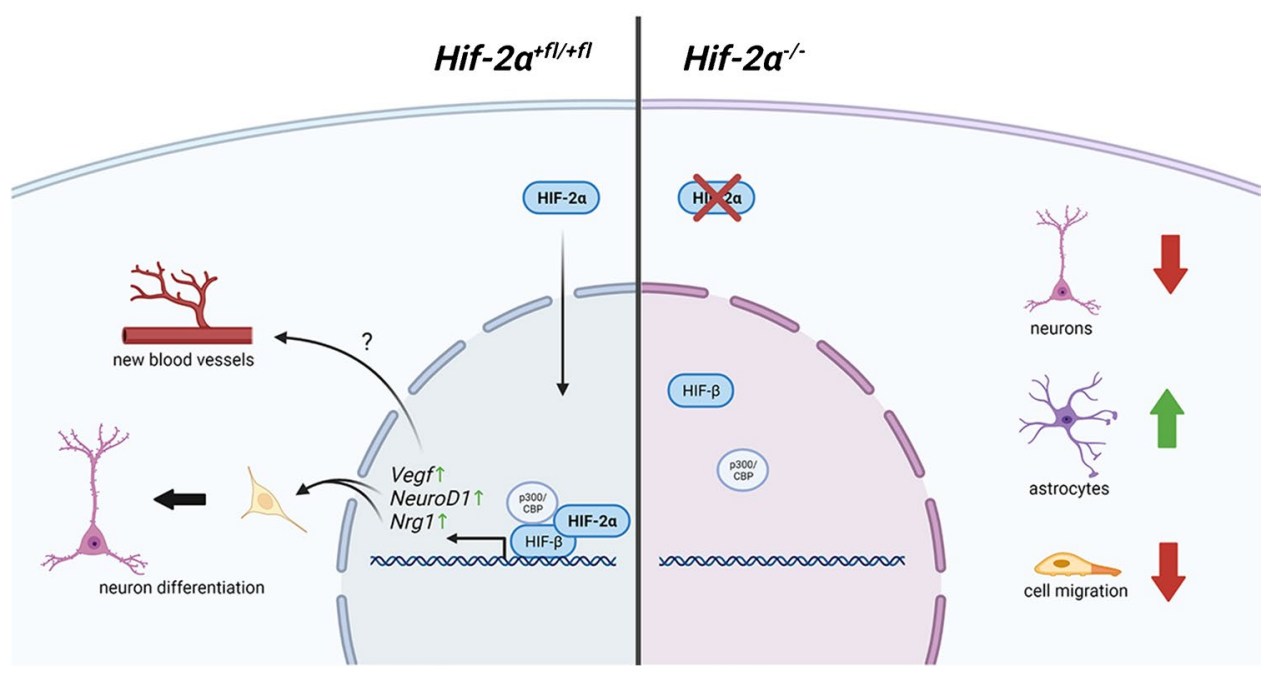

Fig. 5 Neuroregenerative mechanism driven by the hypoxia-inducible factor 2. In animals with functional HIF-2, OGD led to an induction of Vegf, NeuroD1 and $N g f$ expression, thereby increasing the differentiation of neuronal progenitor cells towards neurons. In combination with the increased Vegf expression, this might lead to improved regeneration after stroke. Upon loss of HIF-2, the number of differentiated neurons and cellular migration decreased, whereas the number of astrocytes increased. Thus, HIF-2 stabilization might prove to be valuable target for post-stroke regenerative therapy. Figure created with biorender.com 
of the immunoreactive cells. Due to the distinctly different morphologies between neural progenitor cells and astrocytes, a false count was largely avoided. One trigger for this phenomenon could be the higher gene expression of Notchl since the Notch signalling pathway is responsible for the differentiation of NSCs into astrocytes (Fig. 4b). As a result, proteins, generated by astrocytes, are produced at higher levels, and the effects of astrocyte-associated processes are enhanced. These include the acute erythropoietic response to hypoxic stress, which serves as neuronal protection [44]. However, the analyses of Epo in this study showed that although its expression was significantly stimulated during OGD, no difference between Hif- $2 \alpha^{+f / / f l}$ and Hif- $2 \alpha^{-/-}$was seen (Fig. 2b). It can be assumed that Epo in the brain is not primarily regulated by HIF-2 but by other factors, such as HIF-1. From other cell culture studies and in vivo mice analyses, Epo expression in hepatocytes represents a HIF-2-regulated gene [37, 43]. Preconditioning experiments showed that EPO is a main factor in mediating hypoxic adaptation through its protective effect on subsequent cerebral ischaemia [32]. Also, clinical studies suspected a protective role of EPO [10], but a later multicentre phase II/III trial did not support this hypothesis [11].

To further clarify the variations in cell differentiation, expression analyses of genes that are known to have an important influence on these cell properties were carried out. We observed a significantly higher NeuroDl expression in Hif- $2 \alpha^{+f / / f t}$ after $4 \mathrm{~h}$ of OGD compared to Hif- $2 \alpha^{-/-}$cells; this suggests that HIF- $2 \alpha$ is essential for differentiation and thus new formation of neurons after ischaemic damage (Fig. 4a). This is supported by the fact that protein neurogenic differentiation 1 (NEUROD1) possesses a decisive function for neuronal differentiation and maturation (Fig. 5) [15]. In vivo enforcement of transcriptional factors, such as NEUROD1, successfully induced ectopic neuronal cells in the ipsilateral cerebral cortex and lateral striatum of the poststroke mice brain [46] and worked as inducers to convert somatic cells into neuronal cells [17, 34, 41]. A subsequent analysis of $\mathrm{Nrgl}$ showed an expression pattern similar to NeuroD1. The dependence of proliferation on neuregulin-1 (NRG1) has already been shown in murine embryonic NSCs [24]. Furthermore, NRG1 signalling was highlighted as neuroprotective upon ischaemic lesion both in vitro and in vivo [29, 40]. Maintenance and survival of the neurons, on the other hand, are probably not regulated by HIF- $2 \alpha$. Expression of glutamate (NMDA) receptor subunit zeta-1 (Grinl) as a result of OGD and migration is significantly reduced in the control, but there was no difference between Hif- $2 \alpha^{+f / /+f l}$ and $H i f-2 \alpha^{-/-}$after OGD treatment (Fig. 4 a). GRIN1 is important for connectivity between cells and the maintenance of neurons [1,23]. Nevertheless, it has been shown that the overexpression of NMDA receptor is more likely to initiate cell death of neurons than to maintain it [1].
Therefore, the reduced expression of Grinl as a result of OGD could represent a protective mechanism that promotes neuronal survival at the expense of cell communication.

Translated to the treatment of stroke patients, these insights could help to improve the post-stroke outcome. A boosted stabilization of HIF- $2 \alpha$ could support the regeneration of damaged brain tissue by promoting proliferation and differentiation of neurons. These newly generated neurons would potentially be able to compensate for the cell loss suffered. However, neurons that have migrated into the affected brain area are only capable of survival to a limited extent, as they presumably lack the adequate support of neighbouring astrocytes. In this context, it is interesting that people living at high altitude, such as in the Tibet Autonomous Region, who are permanently exposed to hypoxia, rank among the top incidence of stroke in China. Changes in the HIF-2 $\alpha$ gene have been well-described in Tibetans and associated with the milder increase in haemoglobin compared to lowlanders [4]. Still, there are both gain-of-function and lossof-function changes reported in $H I F-2 \alpha$, and genetic adaptation to high altitude relies on more than one gene. Elevated haemoglobin levels and vascular abnormalities in Tibet may contribute to the increase in blood viscosity and facilitate the formation of tiny thrombi in the cerebral circulation system [5, 6]. For both reasons, highlanders have a higher risk of stroke and a worse outcome, because hypoxia next to higher blood viscosity might damage endothelial cells and activate inflammatory responses [5, 6]. Potentially, the reduced HIF-2 activity with respect to erythropoiesis also reduces the protective function of HIF-2 in the brain.

By studying the effect of HIF-2 on astrocytes in ischaemia more closely, the performed analyses highlighted HIF-2 as a regulator for the differentiation of adult astrocytes (Fig. 3). A targeted destabilization of HIF-2, by, e. g. PHDs, would probably increase the astrocyte count and provide migrating neurons with the supporting basis to integrate into the existing cell network. This could increase the survival rate of immigrated cells and promote the regeneration of damaged tissue. However, it is quite possible that the reduction of HIF-2 levels could cause other problems, such as increased formation of glial scars, because the tasks and functions of HIF and its target genes are highly complex. The other way around, PHD inhibition seems to be an effective method to promote neuroprotection [27, 30, 38]. In particular, PHD2, as the most abundant HIF regulator in the brain, is a promising target for stroke treatment [33]. Recently, a PHD inhibitor called roxadustat (FG-4592) was approved to treat anaemia by increasing EPO production. In brain research, therapeutic approaches also focus on oral PHD inhibitors [18, 47]. The PHD inhibitor FG-4497 displayed a promising potential in preventing neuronal damage and vascular leakage after a stroke [35]. Additionally, GSK360A decreased post-stroke 
brain injury as well as sensory, motor and cognitive behavioural deficits in rats [47]. Nevertheless, an uncontrolled or widespread inhibition of HIF may promote regeneration in some areas while potentially damaging cells in others. In squamous epithelial cells in head and neck tumours, it has already been shown that EGFR activation via HIF- $2 \alpha$ leads to more aggressive tumour growth, which in turn can be associated with increased motility and migration ability [25]. However, the HIF signalling pathway, and in particular HIF-2, can be seen as a valuable candidate for developing new therapeutic options for stroke patients.

\section{Conclusion}

It should be noted that HIF-2 in the brain performs functions which in part are fundamentally different from those previously known from other tissues. There is an interplay between HIF-1 and HIF 2 in the regulation of known target genes. Essential functions of brain regeneration seem to be influenced by the positive effect of HIF-2 on neuron differentiation by means of targeted gene regulation under hypoxic conditions. These processes are likely based on complex signalling pathways such as the Notch signalling pathway. However, the repair mechanisms triggered by HIF-2 are perhaps limited and focus more on fine-tuning the neural network. Based on the findings in this study, we hypothesize that HIF-2 stabilization after a stroke is beneficial during migration and differentiation, whereas HIF-2 stabilization during establishment and survival could be damaging. Therefore, the critical time window for administering the drug needs to be established carefully. Potential therapeutic approaches include the controlled inhibition of PHDs to increase HIF-2 accumulation, thus promoting the neuroprotective effects of the HIF-2 signalling pathway.

\begin{abstract}
Author contribution Conceived or designed the study: TL, JF and TS; performed research: TL; analysed data: TL; contributed new methods or models: TL and TS; wrote the paper: TL, JF and TS.
\end{abstract}

Funding Open Access funding enabled and organized by Projekt DEAL.

Data availability Not applicable.

Code availability Not applicable.

\section{Declarations}

Ethics approval Not applicable.

Consent to participate Not applicable.
Consent for publication Not applicable.

Conflict of interest The authors declare no competing interests.

Open Access This article is licensed under a Creative Commons Attribution 4.0 International License, which permits use, sharing, adaptation, distribution and reproduction in any medium or format, as long as you give appropriate credit to the original author(s) and the source, provide a link to the Creative Commons licence, and indicate if changes were made. The images or other third party material in this article are included in the article's Creative Commons licence, unless indicated otherwise in a credit line to the material. If material is not included in the article's Creative Commons licence and your intended use is not permitted by statutory regulation or exceeds the permitted use, you will need to obtain permission directly from the copyright holder. To view a copy of this licence, visit http://creativecommons.org/licenses/by/4.0/.

\section{References}

1. Arundine M, Tymianski M (2004) Molecular mechanisms of glutamate-dependent neurodegeneration in ischemia and traumatic brain injury. Cell Mol Life Sci 61:657-668. https://doi.org/10. 1007/s00018-003-3319-x

2. Arvidsson A, Collin T, Kirik D, Kokaia Z, Lindvall O (2002) Neuronal replacement from endogenous precursors in the adult brain after stroke. Nat Med 8:963-970. https://doi.org/10.1038/ $\mathrm{nm} 747$

3. Barteczek P, Li L, Ernst AS, Bohler LI, Marti HH, Kunze R (2017) Neuronal HIF-1alpha and HIF-2alpha deficiency improves neuronal survival and sensorimotor function in the early acute phase after ischemic stroke. J Cereb Blood Flow Metab 37:291306. https://doi.org/10.1177/0271678X15624933

4. Bigham AW, Lee FS (2014) Human high-altitude adaptation: forward genetics meets the HIF pathway. Genes Dev 28:2189-2204. https://doi.org/10.1101/gad.250167.114

5. Carroll VA, Ashcroft M (2006) Role of hypoxia-inducible factor (HIF)-1alpha versus HIF-2alpha in the regulation of HIF target genes in response to hypoxia, insulin-like growth factor-I, or loss of von Hippel-Lindau function: implications for targeting the HIF pathway. Cancer Res 66:6264-6270. https://doi.org/10.1158/ 0008-5472.CAN-05-2519

6. Cheng JC, Klausen C, Leung PC (2013) Hypoxia-inducible factor 1 alpha mediates epidermal growth factor-induced down-regulation of E-cadherin expression and cell invasion in human ovarian cancer cells. Cancer Lett 329:197-206. https://doi.org/10.1016/j. canlet.2012.10.029

7. Choi KC, Yoo DS, Cho KS, Huh PW, Kim DS, Park CK (2008) Effect of single growth factor and growth factor combinations on differentiation of neural stem cells. J Korean Neurosurg Soc 44:375-381. https://doi.org/10.3340/jkns.2008.44.6.375

8. Conte C, Riant E, Toutain C, Pujol F, Arnal JF, Lenfant F, Prats AC (2008) FGF2 translationally induced by hypoxia is involved in negative and positive feedback loops with HIF-1alpha. PLoS One 3:e3078. https://doi.org/10.1371/journal.pone.0003078

9. Dayan F, Roux D, Brahimi-Horn MC, Pouyssegur J, Mazure NM (2006) The oxygen sensor factor-inhibiting hypoxia-inducible factor- 1 controls expression of distinct genes through the bifunctional transcriptional character of hypoxia-inducible factor-1alpha. Cancer Res 66:3688-3698. https://doi.org/10.1158/0008-5472. CAN-05-4564

10. Ehrenreich H, Aust C, Krampe H, Jahn H, Jacob S, Herrmann M, Siren AL (2004) Erythropoietin: novel approaches to 
neuroprotection in human brain disease. Metab Brain Dis 19:195206. https://doi.org/10.1023/b:mebr.0000043969.96895.3c

11. Ehrenreich H, Weissenborn K, Prange H, Schneider D, Weimar C, Wartenberg K, Schellinger PD, Bohn M, Becker H, Wegrzyn M, Jahnig P, Herrmann M, Knauth M, Bahr M, Heide W, Wagner A, Schwab S, Reichmann H, Schwendemann G, Dengler R, Kastrup A, Bartels C, Group EPOST (2009) Recombinant human erythropoietin in the treatment of acute ischemic stroke. Stroke 40:e647-656. https://doi.org/10.1161/STROKEAHA.109.564872

12. Epstein AC, Gleadle JM, McNeill LA, Hewitson KS, O’Rourke J, Mole DR, Mukherji M, Metzen E, Wilson MI, Dhanda A, Tian YM, Masson N, Hamilton DL, Jaakkola P, Barstead R, Hodgkin J, Maxwell PH, Pugh CW, Schofield CJ, Ratcliffe PJ (2001) C. elegans EGL-9 and mammalian homologs define a family of dioxygenases that regulate HIF by prolyl hydroxylation. Cell 107:43-54. https://doi.org/10.1016/s0092-8674(01)00507-4

13. Forsythe JA, Jiang BH, Iyer NV, Agani F, Leung SW, Koos RD, Semenza GL (1996) Activation of vascular endothelial growth factor gene transcription by hypoxia-inducible factor 1 . Mol Cell Biol 16:4604-4613. https://doi.org/10.1128/mcb.16.9.4604

14. Gao Y, Jing M, Ge R, Lang L (2016) Induction of hypoxia-inducible factor-1alpha by BDNF protects retinoblastoma cells against chemotherapy-induced apoptosis. Mol Cell Biochem 414:77-84. https://doi.org/10.1007/s11010-016-2660-y

15. Gao Z, Ure K, Ables JL, Lagace DC, Nave KA, Goebbels S, Eisch AJ, Hsieh J (2009) Neurod1 is essential for the survival and maturation of adult-born neurons. Nat Neurosci 12:1090-1092. https:// doi.org/10.1038/nn.2385

16. Gotz M, Huttner WB (2005) The cell biology of neurogenesis. Nat Rev Mol Cell Biol 6:777-788. https://doi.org/10.1038/nrm1739

17. Guo Z, Zhang L, Wu Z, Chen Y, Wang F, Chen G (2014) In vivo direct reprogramming of reactive glial cells into functional neurons after brain injury and in an Alzheimer's disease model. Cell Stem Cell 14:188-202. https://doi.org/10.1016/j.stem.2013.12. 001

18. Harten SK, Ashcroft M, Maxwell PH (2010) Prolyl hydroxylase domain inhibitors: a route to HIF activation and neuroprotection. Antioxid Redox Signal 12:459-480. https://doi.org/10.1089/ars. 2009.2870

19. Holtzman DM, Lee S, Li Y, Chua-Couzens J, Xia H, Bredt DS, Mobley WC (1996) Expression of neuronal-NOS in developing basal forebrain cholinergic neurons: regulation by NGF. Neurochem Res 21:861-868. https://doi.org/10.1007/BF02532310

20. Kleszka K, Leu T, Quinting T, Jastrow H, Pechlivanis S, Fandrey J, Schreiber T (2020) Hypoxia-inducible factor-2 $\alpha$ is crucial for proper brain development. Sci Rep 10:19146. https://doi.org/10. 1038/s41598-020-75838-4

21. Ko CY, Tsai MY, Tseng WF, Cheng CH, Huang CR, Wu JS, Chung HY, Hsieh CS, Sun CK, Hwang SP, Yuh CH, Huang CJ, Pai TW, Tzou WS, Hu CH (2011) Integration of CNS survival and differentiation by HIF2alpha. Cell Death Differ 18:1757-1770. https://doi.org/10.1038/cdd.2011.44

22. Kunze R, Zhou W, Veltkamp R, Wielockx B, Breier G, Marti HH (2012) Neuron-specific prolyl-4-hydroxylase domain 2 knockout reduces brain injury after transient cerebral ischemia. Stroke 43:2748-2756. https://doi.org/10.1161/STROKEAHA.112. 669598

23. Lau A, Tymianski M (2010) Glutamate receptors, neurotoxicity and neurodegeneration. Pflugers Arch 460:525-542. https://doi. org/10.1007/s00424-010-0809-1

24. Liu Y, Ford BD, Mann MA, Fischbach GD (2005) Neuregulin-1 increases the proliferation of neuronal progenitors from embryonic neural stem cells. Dev Biol 283:437-445. https://doi.org/10. 1016/j.ydbio.2005.04.038

25. Masamoto K, Tanishita K (2009) Oxygen transport in brain tissue. J Biomech Eng 131:074002. https://doi.org/10.1115/1.3184694
26. Moors M, Rockel TD, Abel J, Cline JE, Gassmann K, Schreiber T, Schuwald J, Weinmann N, Fritsche E (2009) Human neurospheres as three-dimensional cellular systems for developmental neurotoxicity testing. Environ Health Perspect 117:1131-1138. https:// doi.org/10.1289/ehp.0800207

27. Nagel S, Papadakis M, Chen R, Hoyte LC, Brooks KJ, Gallichan D, Sibson NR, Pugh C, Buchan AM (2011) Neuroprotection by dimethyloxalylglycine following permanent and transient focal cerebral ischemia in rats. J Cereb Blood Flow Metab 31:132-143. https://doi.org/10.1038/jcbfm.2010.60

28. Nasyrov E, Nolan KA, Wenger RH, Marti HH, Kunze R (2019) The neuronal oxygen-sensing pathway controls postnatal vascularization of the murine brain. FASEB J 33:12812-12824. https:// doi.org/10.1096/fj.201901385RR

29. Navarro-Gonzalez C, Huerga-Gomez A, Fazzari P (2019) Nrg1 intracellular signaling is neuroprotective upon stroke. Oxid Med Cell Longev 2019:3930186. https://doi.org/10.1155/2019/39301 86

30. Ogle ME, Gu X, Espinera AR, Wei L (2012) Inhibition of prolyl hydroxylases by dimethyloxaloylglycine after stroke reduces ischemic brain injury and requires hypoxia inducible factor1alpha. Neurobiol Dis 45:733-742. https://doi.org/10.1016/j. nbd.2011.10.020

31. Parent JM, Vexler ZS, Gong C, Derugin N, Ferriero DM (2002) Rat forebrain neurogenesis and striatal neuron replacement after focal stroke. Ann Neurol 52:802-813. https://doi.org/10.1002/ ana.10393

32. Prass K, Scharff A, Ruscher K, Lowl D, Muselmann C, Victorov I, Kapinya K, Dirnagl U, Meisel A (2003) Hypoxia-induced stroke tolerance in the mouse is mediated by erythropoietin. Stroke 34:1981-1986. https://doi.org/10.1161/01.STR.00000 80381.76409.B2

33. Rabie T, Kunze R, Marti HH (2011) Impaired hypoxic response in senescent mouse brain. Int J Dev Neurosci 29:655-661. https://doi.org/10.1016/j.ijdevneu.2011.06.003

34. Ranjan AK, Briyal S, Khandekar D, Gulati A (2020) Sovateltide (IRL-1620) affects neuronal progenitors and prevents cerebral tissue damage after ischemic stroke. Can J Physiol Pharmacol. https://doi.org/10.1139/cjpp-2020-0164

35. Reischl S, Li L, Walkinshaw G, Flippin LA, Marti HH, Kunze R (2014) Inhibition of HIF prolyl-4-hydroxylases by FG-4497 reduces brain tissue injury and edema formation during ischemic stroke. PLoS One 9:e84767. https://doi.org/10.1371/ journal.pone.0084767

36. Schulz K, Milke L, Rubsamen D, Menrad H, Schmid T, Brune B (2012) HIF-1alpha protein is upregulated in HIF-2alpha depleted cells via enhanced translation. FEBS Lett 586:16521657. https://doi.org/10.1016/j.febslet.2012.04.039

37. Scortegagna M, Ding K, Zhang Q, Oktay Y, Bennett MJ, Bennett M, Shelton JM, Richardson JA, Moe O, Garcia JA (2005) HIF-2alpha regulates murine hematopoietic development in an erythropoietin-dependent manner. Blood 105:3133-3140. https://doi.org/10.1182/blood-2004-05-1695

38. Siddiq A, Ayoub IA, Chavez JC, Aminova L, Shah S, LaManna JC, Patton SM, Connor JR, Cherny RA, Volitakis I, Bush AI, Langsetmo I, Seeley T, Gunzler V, Ratan RR (2005) Hypoxiainducible factor prolyl 4-hydroxylase inhibition. A target for neuroprotection in the central nervous system. J Biol Chem 280:41732-41743. https://doi.org/10.1074/jbc.M504963200

39. Sinor AD, Irvin SM, Cobbs CS, Chen J, Graham SH, Greenberg DA (1998) Hypoxic induction of vascular endothelial growth factor (VEGF) protein in astroglial cultures. Brain Res 812:289291. https://doi.org/10.1016/s0006-8993(98)00976-7

40. Surles-Zeigler MC, Li Y, Distel TJ, Omotayo H, Ge S, Ford BD (2018) Transcriptomic analysis of neuregulin-1 regulated genes following ischemic stroke by computational identification of 
promoter binding sites: a role for the ETS-1 transcription factor. PLoS One 13:e0197092. https://doi.org/10.1371/journal.pone. 0197092

41. Vierbuchen T, Ostermeier A, Pang ZP, Kokubu Y, Sudhof TC, Wernig M (2010) Direct conversion of fibroblasts to functional neurons by defined factors. Nature 463:1035-1041. https://doi. org/10.1038/nature08797

42. Wang GL, Jiang BH, Rue EA, Semenza GL (1995) Hypoxiainducible factor 1 is a basic-helix-loop-helix-PAS heterodimer regulated by cellular O2 tension. Proc Natl Acad Sci U S A 92:5510-5514. https://doi.org/10.1073/pnas.92.12.5510

43. Warnecke C, Zaborowska Z, Kurreck J, Erdmann VA, Frei U, Wiesener M, Eckardt KU (2004) Differentiating the functional role of hypoxia-inducible factor (HIF)-1alpha and HIF-2alpha (EPAS-1) by the use of RNA interference: erythropoietin is a HIF-2alpha target gene in Hep3B and Kelly cells. FASEB J 18:1462-1464. https://doi.org/10.1096/fj.04-1640fje

44. Weidemann A, Kerdiles YM, Knaup KX, Rafie CA, Boutin AT, Stockmann C, Takeda N, Scadeng M, Shih AY, Haase VH, Simon MC, Kleinfeld D, Johnson RS (2009) The glial cell response is an essential component of hypoxia-induced erythropoiesis in mice. J Clin Invest 119:3373-3383. https://doi.org/10.1172/JCI39378
45. Wobben R, Husecken Y, Lodewick C, Gibbert K, Fandrey J, Winning S (2013) Role of hypoxia inducible factor-1alpha for interferon synthesis in mouse dendritic cells. Biol Chem 394:495-505. https://doi.org/10.1515/hsz-2012-0320

46. Yamashita T, Shang J, Nakano Y, Morihara R, Sato K, Takemoto M, Hishikawa N, Ohta Y, Abe K (2019) In vivo direct reprogramming of glial linage to mature neurons after cerebral ischemia. Sci Rep 9:10956. https://doi.org/10.1038/s41598-019-47482-0

47. Zhou J, Li J, Rosenbaum DM, Zhuang J, Poon C, Qin P, Rivera K, Lepore J, Willette RN, Hu E, Barone FC (2017) The prolyl 4-hydroxylase inhibitor GSK360A decreases post-stroke brain injury and sensory, motor, and cognitive behavioral deficits. PLoS One 12:e0184049. https://doi.org/10.1371/journal.pone.0184049

Publisher's note Springer Nature remains neutral with regard to jurisdictional claims in published maps and institutional affiliations. 